\title{
Frailty, depression, and quality of life: a study with elderly caregivers
}

\author{
Fragilidade, depressão e qualidade de vida: um estudo com idosos cuidadores \\ Fragilidad, depresión y calidad de vida: un estudio con cuidadores ancianos
}

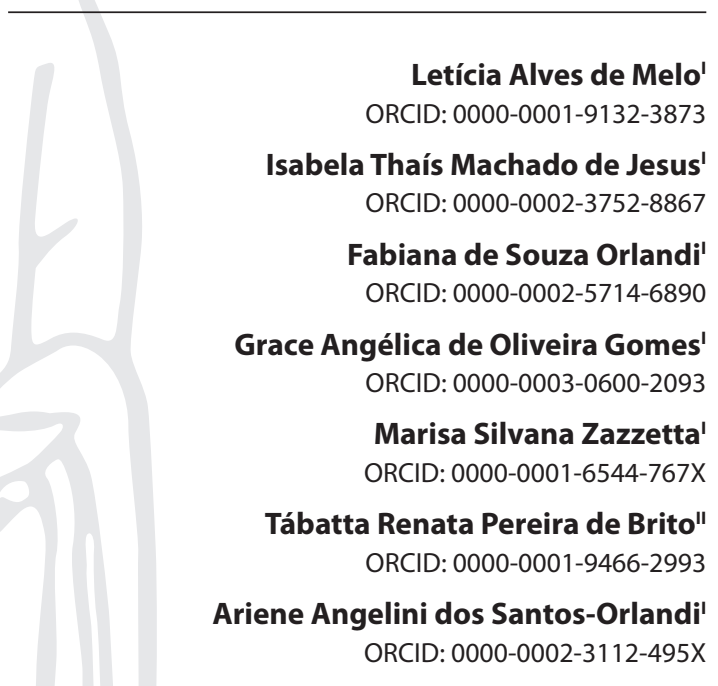

'Universidade Federal de São Carlos. São Carlos, São Paulo, Brazil. "Universidade Federal de Alfenas. Alfenas, Minas Gerais, Brazil.

How to cite this article: Melo LA, Machado ITJ, Orlandi FS, Gomes GAO, Zazzetta MS, Brito TRP, et al. Frailty, depression, and quality of life: a study with elderly caregivers. Rev Bras Enferm. 2020;73(Suppl 3):e20180947. doi: http://dx.doi.org/10.1590/0034-7167-2018-0947

Corresponding author:

Ariene Angelini dos Santos-Orlandi

E-mail: arieneangelini@yahoo.com.br

EDITOR IN CHIEF: Dulce Barbosa ASSOCIATE EDITOR: Maria Saraiva

\section{ABSTRACT}

Objective: to analyze the relationship between frailty, depressive symptoms, and quality of life of elderly caregivers of other elderly living in high social vulnerability. Methods: a descriptive, correlational and cross-sectional study conducted with 40 elderly caregivers. A questionnaire to characterize elderly caregivers, the Fried frailty phenotype, the Geriatric Depression Scale (to screen depressive symptoms) and the Short-Form 6 Dimension (to assess quality of life) were used. For data analysis, Student's t-test, ANOVA, Pearson's $x^{2}$ and Fisher's exact test were used. Results: most were pre-frail (52.5\%) and had no evidence of depressive symptoms $(57.5 \%)$. They presented, on average, a score of $0.76( \pm 0.1)$ in relation to quality of life. Statistical significance was observed between the average scores of quality of life with depressive symptoms $(p=0.012)$ and frailty level $(p=0.004)$. Conclusion: frail elderly caregivers with depressive symptoms had a worse perception of quality of life.

Descriptors: Caregivers; Frail Elderly; Depression; Quality of Life; Geriatric Nursing.

\section{RESUMO}

Objetivo: analisar a relação entre fragilidade, sintomas depressivos e qualidade de vida de idosos cuidadores de outros idosos inseridos em contexto de alta vulnerabilidade social. Métodos: estudo descritivo, correlacional e transversal, realizado com 40 idosos cuidadores. Foram aplicados: questionário para caracterização do idoso cuidador, fenótipo de fragilidade de Fried, Escala de Depressão Geriátrica (rastrear sintomas depressivos) e Questionário ShortForm 6 Dimensions (avaliar qualidade de vida). Na análise dos dados, utilizou-se Teste t de Student, ANOVA, $x^{2}$ de Pearson e Exato de Fisher. Resultados: a maioria dos idosos cuidadores estavam pré-frágeis (52,5\%) e sem indícios de sintomas depressivos (57,5\%). Apresentaram, em média, um escore de $0,76( \pm 0,1)$ em relação à qualidade de vida. Observou-se significância estatística entre os escores médios de qualidade de vida com sintomas depressivos $(p=0,012)$ e nível de fragilidade $(p=0,004)$. Conclusão: idosos cuidadores frágeis e com sintomas depressivos apresentaram pior percepção sobre a qualidade de vida.

Descritores: Cuidadores; Idoso Fragilizado; Depressão; Qualidade de Vida; Enfermagem Geriátrica.

\section{RESUMEN}

Objetivo: analizar la relación entre fragilidad, síntomas depresivos y calidad de vida de cuidadores ancianos de otras personas ancianas insertadas en un contexto de alta vulnerabilidad social. Métodos: estudio descriptivo, correlacional y transversal, realizado con 40 cuidadores ancianos. Se utilizó un cuestionario para caracterizar al cuidador anciano, el fenotipo de fragilidad de Fried, la Escala de Depresión Geriátrica (seguimiento de los síntomas depresivos) y el cuestionario Short-Form 6 Dimensions (evaluación de la calidad de vida). En el análisis de datos, se utilizaron la prueba t de Student, ANOVA, $x^{2}$ de Pearson y la prueba exacta de Fisher. Resultados: la mayoría de los cuidadores ancianos eran prefrágiles (52.5\%) y sin evidencia de síntomas depresivos (57.5\%). Presentaron, en promedio, una puntuación de $0.76( \pm 0.1)$ en relación con la calidad de vida. Se observó significación estadística entre los puntajes promedio de calidad de vida con síntomas depresivos $(p=0.012)$ y nivel de fragilidad $(p=0.004)$. Conclusión: los cuidadores ancianos frágiles con síntomas depresivos tenían una peor percepción de la calidad de vida.

Descriptores: Cuidadores; Anciano Frágil; Depressión; Calidad de Vida; Enfermería Geriátrica. 


\section{INTRODUCTION}

Due to greater longevity, elderly individuals may show a decline in their functional performance, thus causing a condition of greater dependence and consequent need for care ${ }^{(1)}$.

In Brazil, due to the new family arrangements and the increasing number of elderly people, there is a higher prevalence of elderly people caring for other more dependent elderly people ${ }^{(2)}$. Researchers point out that about $16 \%$ of caregivers are between 61 and 70 years old $\mathrm{d}^{(3)}$. Elderly caregivers living in settings of high social vulnerability are more exposed to stressors and may be affected by multimorbidity ${ }^{(4)}$.

Frailty ${ }^{(5-6)}$ and depressive symptom ${ }^{(7)}$ in elderly individuals is high and can negatively affect their quality of life and wellbeing ${ }^{(8)}$. When referring to contexts of high social vulnerability, this prevalence may be even higher ${ }^{(9)}$. Given these conditions and countless chores present in an exhausting routine, there can be a direct impact both on the health and quality of life of caregivers and on care ${ }^{(10)}$.

Clinical studies that sought the relationship between frailty and depressive symptoms in relation to elderly individuals were found in the literature ${ }^{(6,11)}$. A survey carried out in Minas Gerais with 360 community elderly people aimed to know the prevalence and factors associated with frailty. The authors identified that $47.2 \%$ were fragile. Depressive symptoms was a variable associated with frailty ${ }^{(6)}$.

A study was carried out with 721 elderly people aged 60 and over from Singapore to estimate the prevalence of frailty among elderly community members and to investigate the association between frailty level and depressive symptoms. Frailty prevalence in the population studied was $24.5 \%$. As elderly individuals became fragile, they reported depressive symptoms. The authors concluded that frailty level was independently associated with depressive symptoms among elderly community members ${ }^{(11)}$.

Fragile elderly people with depressive symptoms can have a negative impact on well-being and quality of life ${ }^{(8)}$. A study with 374 elderly people aged 75 and over was carried out in the Netherlands to assess the quality of life of frail and non-frail elderly people. The results showed that frail elderly people experienced lower quality of life, on average, than non-frail elderly people. The components of frailty and depressive symptoms were associated with a worse quality of life ${ }^{(12)}$.

Considering the impact of frailty syndrome and depressive symptoms on quality of life, as well as the increase in spending on health services resulting from adverse events, it is necessary to investigate this relationship. Moreover, it is worth mentioning that no studies were found that investigated the relationship of these variables within elderly caregivers inserted in a setting of high social vulnerability, which justifies the academic relevance of this research.

As a social relevance, it is noteworthy that the findings of this research can raise discussions in the scope of public policies aimed at elderly caregivers and intensify the interest of researchers in investigating the insights related to the caregivers' health in vulnerable contexts in primary care. It is known that life situation, social engagement and the environment are social factors that can influence health issues ${ }^{(13)}$. It is worth mentioning that considering the
Brazilian life expectancy and the international recommendations of aging in the community, care tends to be carried out at home and caregivers have to be near individuals cared for ${ }^{(14)}$.

The innovation of this research is in the understanding of how frailty, depression, and quality of life present themselves in elderly caregivers in a vulnerable environment. It is known that social determinants can aggravate health conditions ${ }^{(13)}$. It is believed that these results may assist health professionals in directing an immediate or long-term care plan aimed at the needs of these elderly caregivers in primary health care, which is the baseline in the health system.

\section{OBJECTIVE}

This study aims to analyze the relationship between frailty, depressive symptoms, and quality of life of elderly caregivers of other elderly individuals living in high social vulnerability.

\section{METHODS}

\section{Ethical aspects}

The ethical aspects disciplined by Resolution 466/2012 regulated by the Brazilian National Health Council (Conselho Nacional de Saúde) were observed and respected. This study was approved by the Research Ethics Committee on 03/13/2018.

\section{Design, period, and place of study}

This is a descriptive, correlational and cross-sectional study based on quantitative research assumptions. Its structure followed the guidelines present in STROBE (Strengthening the Reporting of Observational Studies in Epidemiology).

This study belongs to the research entitled "Ferramenta para monitoramento de níveis de fragilidade e fatores associados em idosos atendidos pelo Núcleo de Apoio à Saúde da Família (NASF) no município de São Carlos". This research assessed 304 elderly people. The individuals assessed belong to the five Family Health Units (FHU) in the "Cidade Aracy" Regional Health Administration (Administração Regional de Saúde, abbreviated ARES) in the municipality of São Carlos, which presents the greatest social vulnerability ${ }^{(9)}$.

Data collection took place between January and October 2015, by previously trained undergraduate and graduate students and was performed in a single session, lasting approximately 90 minutes. Initially, contact was made with the five FHU so that community health workers could provide a list with the names and addresses of all elderly. Eight hundred elderly people registered in these Units were identified. Then, sample calculation was performed considering age, which was divided into age groups (60-64, 65-69, 70-74, 75-79 and 80 years and older) and sex (male and female). For sample calculation, the alpha significance level was set at $5 \%$ (alpha $=0.05)$ and the sample error at $5 \%(d=0.05)$. Due to the absence of preliminary information on estimates of the population of interest, an estimate of $50 \%$ was used $(p=0.50)$. Thus, the calculation performed totaled 304 elderly people. The households were identified and a home visit was carried out in order to inform them about the objective of the research and 
to invite them to participate in the study. In case of acceptance, a new home visit was scheduled to apply the data collection protocol. Of the 304 elderly people assessed, 40 were caregivers.

This study was developed from data belonging to the database of that research previously mentioned.

\section{Sample, and inclusion and exclusion criteria}

In relation to the large study, elderly people aged 60 years and older, registered in the FHUs of "Cidade Aracy" ARES, assisted by NASF (Núcleo de Apoio à Saúde da Família - Family Health Support Center), able to understand and communicate verbally, who agreed to participate in the study and signed the Informed Consent Form were included. Elderly people with diseases or sequel that prevent tests (severe motor deficits, hearing or aphasia), wheelchair users or those with terminal illnesses were excluded.

Elderly individuals in the database who were primary caregivers of other elderly, with a minimum age of 60 years old, comprised the sample of this study. The exclusion criterion used was not to live in the same house as elderly individuals cared for. Considering these criteria, the sample was composed of 40 elderly caregivers.

\section{Study protocol}

The main study's data collection took place in a single session and started after consent of elderly participants by reading and signing the Informed Consent Form.

Sociodemographic and health data were collected through a questionnaire previously built by the researchers with information on sex, age, color, marital status, education, family arrangement, current job, retirement, income, health insurance, subjective health assessment, presence of comorbidity, smoking, and alcoholism.

The phenotype proposed by Fried ${ }^{(15)}$ was adopted to assess frailty. The operational definition encompasses five elements: 1) Unintentional weight loss: the following question was asked to caregivers: "In the past twelve months, do you think you have lost weight without going on diet?". If so, if that weight loss was $4.5 \mathrm{~kg}$ or more or $5 \%$ of body weight in the previous year, the elderly individual scored on this criterion; 2) Fatigue: assessed through self-report evoked by two questions from the Center for Epidemiological Studies - Depression (CES-D) (scale for screening depression): (7 - How often, in the past week, did you feel that everything you did required a great deal of effort? and 20 - How often, in the past week, did you feel that you would not be able to carry on with your things?) ${ }^{(16)}$. Elderly individuals who answered "always" or "most of the time" to either of these two questions scored on this criterion; 3) Low handgrip strength: it was measured with a portable hydraulic dynamometer in the dominant hand. Three consecutive measurements of handgrip strength were performed, using the arithmetic mean. To fulfill the criterion, the result was adjusted according to sex and Body Mass Index, according to Fried ${ }^{(15)}$; 4) Low level of caloric expenditure: adapted item. It was assessed through self-report based on the question "Do you think you do less physical activity than you did twelve months ago?" If so, the elderly individual scored on this criterion; 5) Slow gait: indicated by the average time spent traveling $4.6 \mathrm{~m}$ distance, with adjustments according to sex and height, according to Fried ${ }^{(15)}$. Three gait speed measurements were made, using the arithmetic mean. Three or more of the five characteristics of the phenotype indicates frail elderly individuals; one or two means that they are pre-frail state; and none of these characteristics indicate a robust or non-frail elderly individuals ${ }^{(15)}$.

The Geriatric Depression Scale, 15-item version, was used to screen depressive symptoms. At the end, the sum of the score obtained and its interpretation was performed. Results between zero and five points mean absence of depressive symptoms; from six to 15 points, indicate presence of depression ${ }^{(17)}$.

The Short-Form 6 Dimensions (SF-6D Brazil) was used to assess health-related quality of life. The only SF-6D score ranges from zero to one, with zero equal to worst health-related quality of life, and one, best perception of quality of life ${ }^{(18)}$.

\section{Analysis of results, and statistics}

In the descriptive data analysis, distributions of frequencies, means and standard deviations were estimated for the study's continuous variables. For categorical variables, proportions were estimated. Differences between groups were estimated using Fisher's exact and Pearson's $X^{2}$ tests. The Kolmogorov-Smirnov test was used to prove the normality of SF-6D. To compare means, Student's t-test and ANOVA were used. Such statistical tests are recommended to test the statistical difference between means and proportions. The tests were chosen due to the sample showing normal distribution ${ }^{(19)}$. The level of significance was set at $5 \%$. All analyzes were performed using Stata, version 13.0.

\section{RESULTS}

The sample of this study consisted of 40 participants. There was a predominance of female caregivers (67.5\%), aged between 60 and 69 years $(55.0 \%)$, white $(45.0 \%)$, married $(87.5 \%)$ and with education complete primary school (40.0\%). Most lived with their spouse $(92.5 \%)$, did not work $(82.5 \%)$ and was retired (72.5\%). They had a reasonable perception of health $(47.5 \%)$, had no health insurance $(90.0 \%)$ and denied smoking (42.5\%) and alcoholism (90.0\%).

Table 1 shows the distribution of elderly caregivers according to predominant sociodemographic and health aspects.

The most frequently reported diseases by elderly caregivers were chronic obstructive pulmonary disease $(92.5 \%)$, stroke (90.0\%), cancer $(90.0 \%)$, anemia (82.5\%), diabetes (77, 5\%), arthritis (67.5\%), circulatory diseases (67.5\%), and hypertension (62.5\%).

Table 2 shows the distribution of elderly caregivers according to the assessed frailty criteria. Most were pre-frail (52.5\%). As for the frailty criteria, $62.5 \%$ scored on reduced physical activity, $57.5 \%$ for low handgrip strength, $57.5 \%$ for slow gait, $52.5 \%$ for unintentional weight loss, and $35.0 \%$ for fatigue.

According to the Geriatric Depression Scale, $57.5 \%$ of elderly caregivers did not show evidence of depressive symptoms. They had a mean of 4.5 points ( $S D=2.8)$, a median of 4.0 points and a minimum of zero and a maximum of 9.0 on the scale score.

Concerning quality of life (SF-6D), elderly caregivers had, on average, a score of $0.76(S D=0.1)$. Median was 0.77 , with a minimum of 0.4 and a maximum of 1.0 . 
Table 1 - Distribution of elderly caregivers according to predominant sociodemographic and health aspects, São Carlos, São Paulo, Brazil, 2015 ( $\mathrm{n=40)}$

\begin{tabular}{|c|c|c|c|c|c|c|c|}
\hline Variable & Category & $\mathbf{n}$ & $\%$ & Mean & SD & Median & Min-Max \\
\hline Sex & Female & 27 & 67.5 & & & & \\
\hline Age (years) & & & & 70.1 & 8.2 & 68.5 & $60-98$ \\
\hline Age group & 60-69 years old & 22 & 55.0 & & & & \\
\hline Color & White & 18 & 45.0 & & & & \\
\hline Marital status & Married & 35 & 87.5 & & & & \\
\hline Years of study & & & & 1.8 & 2.3 & 1.0 & $0-12$ \\
\hline Education & Elementary school & 16 & 40.0 & & & & \\
\hline Family arrangement & Living with a partner & 37 & 92.5 & & & & \\
\hline Currently working & No & 33 & 82.5 & & & & \\
\hline Retirement & Yes & 29 & 72.5 & & & & \\
\hline Income (reais*) & & & & 781.2 & 382.0 & 780.0 & $0-2000.0$ \\
\hline Health insurance & No & 36 & 90.0 & & & & \\
\hline Perception of health & Adequate & 19 & 47.5 & & & & \\
\hline Smoking & Never smoked & 17 & 42.5 & & & & \\
\hline Ethics & No & 36 & 90.0 & & & & \\
\hline
\end{tabular}

Note: SD - standard deviation; Min - minimum value; Max-maximum value; *reais is the Brazilian currency; 1 real corresponds to about 5.21 US dollars).

Table 2 - Distribution of elderly caregivers according to frailty criteria, São Carlos, São Paulo, Brazil, 2015 ( $n=40)$

\begin{tabular}{lccc}
\hline Variables & Categories & $\mathbf{n}$ & $\mathbf{( \% )}$ \\
\hline Unintentional weight loss & No & 16 & 40.0 \\
& Yes & 21 & 52.5 \\
Reduced physical activity & No & 14 & 35.0 \\
& Yes & 25 & 62.5 \\
Fatigue & No & 26 & 65.0 \\
& Yes & 14 & 35.0 \\
Low handgrip strength & No & 17 & 42.5 \\
& Yes & 23 & 57.5 \\
Slow gait & No & 17 & 42.5 \\
& Yes & 23 & 57.5 \\
Fragility level & Non-frail & 17 & 42.5 \\
& Pre-frail & 21 & 52.5 \\
& Frail & 2 & 5.0 \\
\hline
\end{tabular}

Note: *The sum of the percentage frequencies that did not reach $100.0 \%$ is due to the fact that some variables were not answered by all elderly individuals.

Table 3 - Distribution of elderly caregivers according to mood and frailty, São Carlos, São Paulo, Brazil, 2015 ( $n=40$ )

\begin{tabular}{|c|c|c|c|}
\hline \multirow[b]{2}{*}{ Frailty } & \multicolumn{2}{|c|}{ Depressive Symptoms } & \multirow[b]{2}{*}{$p$ value } \\
\hline & $\begin{array}{c}\text { No } \\
n(\%)\end{array}$ & $\begin{array}{c}\text { Yes } \\
\text { n (\%) }\end{array}$ & \\
\hline \multicolumn{4}{|l|}{ Frailty levels } \\
\hline Non-frail & $12(52.2)$ & $5(29.4)$ & $0.132^{1}$ \\
\hline Frail & $11(47.8)$ & $12(70.6)$ & \\
\hline \multicolumn{4}{|c|}{ Components of frailty } \\
\hline \multicolumn{4}{|c|}{ Unintentional weight loss } \\
\hline No & $15(75.0)$ & $3(35.3)$ & $0.017^{2}$ \\
\hline Yes & $5(25.0)$ & $11(64.7)$ & \\
\hline \multicolumn{4}{|c|}{ Reduced physical activity } \\
\hline No & $11(47.8)$ & $3(18.7)$ & $0.062^{2}$ \\
\hline Yes & $12(52.2)$ & $13(81.3)$ & \\
\hline \multicolumn{4}{|l|}{ Fatigue } \\
\hline No & $18(78.3)$ & $8(47.1)$ & $0.044^{1}$ \\
\hline Yes & $5(21.7)$ & $9(52.9)$ & \\
\hline \multicolumn{4}{|c|}{ Low handgrip strength } \\
\hline No & $10(43.5)$ & $7(41.2)$ & $0.571^{1}$ \\
\hline Yes & $13(56.5)$ & $10(58.2)$ & \\
\hline \\
\hline No & $9(39.1)$ & $8(47.1)$ & $0.429^{1}$ \\
\hline Yes & $14(60.9)$ & $9(52.9)$ & \\
\hline
\end{tabular}

Note: ${ }^{1} x^{2}$ de Pearson; ${ }^{2}$ Exato de Fisher.
Table 4 - Mean quality of life score according to frailty and depressive symptoms, São Carlos, São Paulo, Brazil, $2015(\mathrm{n}=40)$

\begin{tabular}{lccc}
\hline Variable & Categories & $\begin{array}{c}\text { Mean } \\
\text { score } \\
\text { (SD) }\end{array}$ & $\begin{array}{c}\boldsymbol{p} \\
\text { value }\end{array}$ \\
\hline Depressive symptoms & $\begin{array}{c}\text { Without depressive symptoms } \\
\text { With depressive symptoms }\end{array}$ & $\begin{array}{c}0.8(0.1) \\
0.7(0.1)\end{array}$ & $0.012^{*}$ \\
Frailty & Non-frail & $1.0(0.0)$ & $0.004^{* *}$ \\
& Pre-frail & $0.8(0.1)$ & \\
Unintentional weight loss & Frail & $0.7(0.1)$ & \\
& No & $0.8(0.1)$ & $0.103^{*}$ \\
Reduced physical activity & Yes & $0.7(0.1)$ & \\
& No & $0.8(0.1)$ & $0.015^{*}$ \\
Fatigue & Yes & $0.7(0.1)$ & \\
& No & $0.8(0.1)$ & $0.318^{*}$ \\
Low handgrip strength & Yes & $0.7(0.2)$ & \\
& No & $0.8(0.1)$ & $0.07^{*}$ \\
Slow gait & Yes & $0.7(0.1)$ & \\
& No & $0.8(0.1)$ & $0.447^{*}$ \\
& Yes & $0.7(0.1)$ & \\
\hline
\end{tabular}

Nota: *Student's t-test; **ANOVA; SD - standard deviation.

Table 3 shows the distribution of elderly caregivers according to mood and frailty. Table 3 shows that $70.6 \%$ of frail elderly people had depressive symptoms. About $64.7 \%$ of the elderly who scored on weight loss, $81.3 \%$ on reduced physical activity criterion, $52.9 \%$ on fatigue, $58.2 \%$ on low handgrip strength and $52.9 \%$ on slow gait criteria showed depressive symptoms. There was statistical significance only between depressive symptoms and unintentional weight loss $(p=0.017)$ and fatigue $(p=0.044)$.

Table 4 shows the mean SF-6D score (quality of life) according to frailty and depressive symptoms. Statistical significance was observed between the mean scores of SF-6D (quality of life) with depressive symptoms $(p=0.012)$, frailty level $(p=0.004)$ and reduced physical activity ( $p=0.015)$. It is noted that frail elderly caregivers, with depressive symptoms and who scored on the reduced physical activity criterion, presented worse quality of life scores, when compared to non-frail elderly people, without depressive symptoms and who did not score for that criterion (Table 4). 


\section{DISCUSSION}

As for the frailty syndrome, most elderly caregivers were prefrail $(52.5 \%)$. Similar results were found in a survey conducted with elderly caregivers in the city of Campinas (SP). Of the 148 respondents, $46.0 \%$ were pre-fragile according to the criteria of the phenotype proposed by Linda Fried ${ }^{(20)}$.

The high percentage of pre-frail elderly people shows the need and importance of carrying out interventions aimed at preventing worsened frailty syndrome, to avoid adverse outcomes and improve quality of life ${ }^{(21)}$. Factors such as lack of social support, low schooling and less access to health services are conditions present in the context of social vulnerability, which can cause worsening health conditions and, consequently, make them weakened ${ }^{(22)}$. Worsened physical health is related to lower levels of psychological well-being, decreased positive affection, reduced satisfaction of individuals who provide care and, consequently, worsened quality of life ${ }^{(23)}$.

In this study, $62.5 \%$ of the elderly caregivers reported reduced physical activity. Similar results were identified in an investigation carried out with 148 elderly caregivers in the city of Campinas (SP), which aimed to assess the multimorbidity, perceived overload and frailty of all interviewees. As a result, they obtained that $42.5 \%$ of the elderly caregivers also scored on reduced physical activity ${ }^{(20)}$.

Scholars point out that reduced mobility, muscle weakness, postural instability and sarcopenia are factors that contribute to declined physical activity by elderly individuals ${ }^{(21)}$. On the other hand, care for elderly individuals can be very demanding of caregivers, who do not have free time to dedicate themselves to other activities, which can develop depression and worsen quality of life ${ }^{(24)}$.

Aerobic and resistance physical exercise is recommended to prevent the onset and progression of the frailty syndrome as it increases the muscle and bone mass of individuals regardless of age. Furthermore, it contributes beneficially to health conditions and perception of quality of life by the elderly population and, consequently, to elderly caregivers ${ }^{(25-26)}$.

Although most of participants in this study did not show signs of depressive symptoms ( $57.5 \%)$, it is necessary to be concerned about the other elderly caregivers who presented them (42.5\%). International researchers have revealed that elderly caregivers report having more depressive symptoms compared to young and elderly caregivers who are not caregivers ${ }^{(27)}$.

A recent literature review was carried out with the aim of analyzing publications related to the assessment of depressive symptoms in caregivers of elderly individuals. Seventeen articles were analyzed, and the results showed that the majority of elderly caregivers had more depressive symptoms than elderly non-caregivers. The authors concluded that the act of caring can generate important emotional consequences when there is no adequate support ${ }^{(28)}$.

The context in which these elderly caregivers are inserted may explain the presence of such symptoms. When performing the task of caring without the support of other family members, elderly caregivers feel lonely, neglecting their own health and do not have time for recreational and leisure activities, factors that can contribute to the onset of depressive symptoms ${ }^{(24)}$. Moreover, the social context characterized as vulnerable expresses a condition of people who are in the process of social exclusion and which involves precarious economic, cultural and social aspects ${ }^{(29)}$.
The literature points to other factors that may be associated with the onset of depressive symptoms among elderly caregivers, such as overload, the aging process itself, physical impairment and lack of support to provide care. As time goes by, feelings of inability to perform actions as they may have arisen in the past, creating anguish ${ }^{(30)}$.

No statistically significant difference was identified between the level of frailty and depressive symptoms; this is in line with the findings of the national ${ }^{(31)}$ and international ${ }^{(7,32)}$ literature, which indicate that depression can generate physiological conditions for the onset or worsened frailty syndrome. Perhaps a possible explanation for this is the small sample size.

There was statistical significance between depressive symptoms and unintentional weight loss $(p=0.017)$ and fatigue $(p=0.044)$. Elderly people with depressive symptoms have higher percentages of unintentional weight loss and fatigue, when compared to elderly people without depressive symptoms.

Elderly people with depressive symptoms may experience hunger and chronic malnutrition, which increases the risks for weight loss $^{(33-34)}$. Depressive symptoms are related to feelings of sadness, social isolation, fatigue and anhedonia, which can contribute to worsening functional performance and reduced physical activity ${ }^{(35)}$. Researchers affirm that the appearance of fatigue is common in elderly people considered as not active. Physical activity can improve functional capacity, making elderly individuals feel physically well and not showing fatigue ${ }^{(36)}$. This explanation is in line with the sample profile of this study, considering that $62.5 \%$ of the elderly caregivers reported reduced physical activity.

Concerning quality of life, elderly individuals had a score of 0.76 , and the closer to 1.0 , the better the quality of life. It can be said that they have a positive outlook on their quality of life. Such a positive perception was also found in the international literature ${ }^{(37)}$. A study carried out in Spain, with 92 primary caregivers of dependent elderly family members, found that $53.3 \%$ perceived their quality of life as "good" or "very good"(37).

Researchers state that the caregivers' physical health and independence to perform activities of daily living are variables that strongly influence self-perception of quality of life. Caregivers with better physical and independent health demonstrate higher levels of well-being and better quality of life ${ }^{(23)}$. Younger older people are less exposed to disabilities related to chronic diseases. Therefore, they manage to remain independent for a longer time, a positive fact for a better perception of quality of life. A positive quality of life can also be related to personal resilience resources, i.e., the use of proper strategies to deal with stressors ${ }^{(38)}$.

A statistically significant difference was identified between quality of life and depressive symptoms $(p=0.012)$, i.e., elderly caregivers with depressive symptoms had a lower average quality of life score when compared to elderly caregivers without depressive symptoms.

An investigation was carried out in the city of Teresina, state of Piauí, with family caregivers of dependent elderly people, in order to assess the quality of life of these caregivers. In assessing the psychological aspects of quality of life, the authors identified that negative feelings, such as anxiety and depression, are frequently reported by these caregivers. It was concluded that depression negatively impacts the quality of life of a dependent elderly caregiver, as it can interact with other body systems and cause somatic diseases ${ }^{(39)}$. 
The literature points out that the family caregiver of an elderly person tends to modify his routine due to the task of caring, which demands time and dedication. Often, there is a reduction in the time to take care of oneself and social isolation, which results in high levels of overload, depressive symptoms and consequent impairment of quality of life ${ }^{(23)}$.

Some family caregivers point out that care can be exhausting and stressful, when there is no support from other family members. In this sense, there is a restriction of social activities, the appearance of depressive symptoms and a negative impact on the quality of life of these individuals ${ }^{(40)}$.

In the present study, there was statistical significance among the mean SF-6D scores with the level of frailty $(p=0.004)$, i.e., frail elderly caregivers had a worse perception of quality of life when compared to elderly non-frail caregivers.

Frail elderly people had decreased homeostatic reserve, reduced resilience and increased vulnerability in the face of stressors. All of these factors can lead to variations in the health status of elderly individuals and have implications for physical and psychological well-being, interfering with the positive perception of their quality of life ${ }^{(33,41-42)}$.

A statistically significant difference was identified between quality of life and reduced physical activity. Elderly people who presented low caloric expenditure in physical activities showed lower quality of life levels than active elderly people. Similar results have been identified in the national literature ${ }^{(43)}$.

A study carried out in Piauí, with 80 elderly women, aimed to compare the level of quality of life between elderly women practicing and not practicing physical activity. The results showed that there was a statistically significant difference between physical activity and quality of life. In other words, better levels of quality of life were observed among elderly women who practiced physical activity ${ }^{(43)}$.

The literature shows that physical activities are beneficial because they boost the functional maintenance of the locomotor system, one of the main responsible for the individual's independence in carrying out activities of daily living. It is known that the preserved functional capacity is closely related to better perceptions of quality of life ${ }^{(43)}$.

There was significance between frailty, quality of life and depression in elderly caregivers. This finding shows that when there is fragility and depressive symptoms, there seems to be an impact on quality of life. These data are relevant to the understanding of how issues related to the health of elderly people in the context of social vulnerability can make them more susceptible to develop other health conditions ${ }^{(13)}$. A study conducted with Mexican elderly people showed a higher prevalence of depression and worse quality of life in frail elderly people. The study authors also report the need to clarify the extent to which poor quality of life in frail elderly people is influenced by adverse events that alter health, such as depression ${ }^{(44)}$.

Given the above, it is necessary to promote and prevent health problems, in order to avoid the occurrence of chronic conditions that can trigger frailty, depression and, consequently, affect the quality of life of elderly caregivers. Monitoring health conditions with assertive interventions can minimize outcomes early ${ }^{(28)}$.

Longitudinal studies with elderly caregivers of other elderly people are recommended to verify the cause and effect relationship between the variables of the present investigation. Furthermore, it is suggested to include variables directly related to care, such as how long elderly caregivers have spent caring for another elderly person, how long in a day caregivers perform care, etc. It would also be desirable to invest in randomized clinical trials in cases of elderly caregivers in a process of frailty, given that the frailty is potentially reversible.

\section{Study limitations}

This study has as a limitation the small sample size. This can be an obstacle to the generalization of the results and the crosssectional design, considering that conclusions cannot be drawn about causality. Underestimated data on the prevalence of frailty and depressive symptoms should be taken into account, since the design of this study did not involve a population sample.

\section{Contributions to nursing, health, and public policies}

The observed results contribute as a warning signal to health professionals about the importance of diagnosing frailty syndrome early and the presence of depressive symptoms among elderly caregivers. The planning of individualized interventions that meet the needs of each elderly caregiver and seek to improve their quality of life can be carried out through a global assessment of these elderly people. Furthermore, public policies of care for elderly caregivers in the context of primary care can be thought of.

\section{CONCLUSION}

The results showed that there is a relationship between frailty, depressive symptoms and quality of life of elderly caregivers of other elderly people. Elderly caregivers who were fragile and had depressive symptoms had a worse perception of quality of life.

This study presents as weaknesses the small sample size and the fact that the results may not apply to elderly caregivers inserted in other contexts.

On the other hand, the awareness of primary health care professionals stands out as a strength considering the importance of early identification of the level of fragility, depressive symptoms, and impaired quality of life. Developing previous and assertive interventions contributes to avoid the involvement of these individuals by both conditions. Moreover, the relevance and innovative character of the theme, the use of validated instruments for the Brazilian context and the fact that elderly individuals live in the community and are not selected based on depressive symptoms or fragility state are also present strengths study.

Future longitudinal research is suggested in order to discover the direction of the relationships found here. Monitoring these elderly caregivers can bring robust evidence for possible readjustments within the scope of public policies and actions to promote health and prevent diseases such as developing support groups to follow these individuals and meet their demands in search of a better quality of life.

\section{FUNDING}

This study was funded by the São Paulo State Research Support Foundation (Fundação de Amparo à Pesquisa do Estado de São Paulo, abbreviated FAPESP; Processes 2014/50104-0 and 2018/04980-3). 


\section{REFERENCES}

1. Confortin SC, Schneider IJ, Antes DL, Cembranel F, Ono LM, Marques LP, et al. Life and health conditions among elderly: results of the EpiFloripa Idoso cohort study. Epidemiol Serv Saúde. 2017;26(2):305-17. doi: 10.5123/s1679-49742017000200008

2. Oliveira NA, Souza EN, Luchesi BM, Inouye K, Pavarini SCI. Stress and optimism of elderlies who are caregivers for elderlies and live with children. Rev Bras Enferm. 2017;70(4):697-703. doi: 10.1590/0034-7167-2017-0088

3. Almeida LPB, Menezes TMO, Freitas AVS, Pedreira LC. Características sociais e demográficas de idosos cuidadores e motivos para cuidar da pessoa idosa em domicílio. Rev Min Enferm. 2018;22:e-1074. doi: 10.5935/1415-2762.20180004

4. Santos-Orlandi AA, Brito TRP, Ottaviani AC, Rossetti ES, Zazzetta MS, Gratão ACM, et al. Profile of older adults caring for other older adults in contexts of high social vulnerability. Esc Anna Nery. 2017;21(1):1-8. doi: 10.5935/1414-8145.20170013

5. Augusti ACV, Falsarella GR, Coimbra AMV. Análise da síndrome da fragilidade em idosos na atenção primária - estudo transversal. Rev Bras Med Fam Comunidade. 2017;12(39):1-9. doi: 10.5712/rbmfc12(39)1353

6. Carneiro JA, Cardoso RR, Durães MS, Guedes MCA, Santos FL, Costa FM, et al. Frailty in the elderly: prevalence and associated factors. Rev Bras Enferm. 2017;70(4):747-52. doi: 10.1590/0034-7167-2016-0633

7. Soysal P, Veronese N, Thompson T, Kahl KG, Fernandes BS, Prina AM, et al. Relationship between depression and frailty in older adults: a systematic review and meta-analysis. Ageing Res Rev. 2017;31(36):78-87. doi: 10.1016/j.arr.2017.03.005

8. Merchant RA, Chen MZ, Tan LW, Lim MY, Ho HK, van Dam RM. Singapore Healthy Older People Everyday (HOPE) Study: prevalence of frailty and associated factors in older adults. JAMDA. 2017;18(8):734-e9. doi: 10.1016/j.jamda.2017.04.020

9. Zazzetta MS, Gomes GAO, Orlandi FS, Gratão ACM, Vasilceac FA, Gramani-Say K, et al. Identifying frailty levels and associated factors in a population living in the context of poverty and social vulnerability. J Frailty Aging. 2017;6(1):29-32. doi: 10.14283/jfa.2016.116

10. Nunes DP, Brito TRP, Duarte YAO, Lebrão ML. Caregivers of elderly and excessive tension associated to care: evidence of the Sabe Study. Rev Bras Epidemiol. 2018;21(Suppl-2):E180020.SUPL.2. doi 10.1590/1980-549720180020.supl.2

11. Ge L, Yap CW, Heng BH. Prevalence of frailty and its association with depressive symptoms among older adults in Singapore. Aging Ment Health. 2018;16:1-6. doi: 10.1080/13607863.2017.1416332

12. Gobbens RJJ. Physical and mental dimensions of quality of life of frail older people. Tijdschr Gerontol Geriatr. 2017;48(4):160-8. doi: 10.1007/ s12439-017-0221-9

13. Godin J, Andrew MK. Frailty and Social Vulnerability. Encyclopedia of Gerontology and Population Aging. 2019. doi: 10.1007/978-3-319-69892-2

14. World Health Organization. World report on ageing and health. 2015. Available at: <https://www.who.int/ageing/events/ world-report-2015-launch/en/>

15. Fried LP, Tangen CM, Walston J, Newman AB, Hirsch C, Gottdiener J, et al. Frailty in older adults: evidence for a phenotype. J Gerontol Biol Sci Med Sci [Internet]. 2001 [cited 2018 Dec 05]56(3):M146-56. Available from: https://www.ncbi.nlm.nih.gov/pubmed/11253156

16. Radloff LS. The CES-D Scale: a self-report depression scale for research in the general population. Appl Psych Meas. 1977;1:385-401. doi:10.1177/014662167700100306

17. Almeida O, Almeida SA. Confiabilidade da versão brasileira da Escala de Depressão em Geriatria (GDS) versão reduzida. Arq Neuropsiquiatr. 1999;57(2):421-6. doi: 10.1590/S0004-282X1999000300013

18. Campolina AG, Bortoluzzo AB, Ferraz MB, Ciconelli RM. Validation of the Brazilian version of the generic six-dimensional short form quality of life questionnaire (SF-6D Brazil). Ciênc Saúde Colet. 2011;16(7):3103-10. doi:10.1590/S1413-81232011000800010

19. Berquó ES, Souza JMPD, Gotlieb SLD. Bioestatística. 2ed. rev. São Paulo: Editora Pedagógica e Universitária Ltda, c1981, 2006.

20. Alves EVC, Flesch LD, Cachioni M, Neri AL, Batistoni SST. The double vulnerability of elderly caregivers: multimorbidity and perceived burden and their associations with frailty. Rev Bras Geriatr Gerontol. 2018;21(3):312-322. doi:10.1590/1981-22562018021.180050

21. Santos PHS, Fernandes MH, Casotti CA, Coqueiro RS, Carneiro JAO. The profile of fragility and associated factors among the elderly registered in a Family Health Unit. Cienc Saude Colet. 2015;20(6):1917-24. doi:10.1590/1413-81232015206.17232014

22. Antunes JFS, Okuno MFP, Lopes MCBT, Campanharo CRV, Batista REA. Frailty assessment of elderly hospitalized at an emergency service of a university hospital. Cogitare Enferm [Internet]. 2015 [cited 2018 Dec 07]20(2):266-73. Available from: http://docs.bvsalud.org/ biblioref/2016/08/1254/39928-157216-1-pb.pdf

23. Flesch LD, Batistoni SST, Neri AL, Cachioni M. Psychological aspects of the quality of life of caregivers of the elderly: an integrative review. Geriatr Gerontol Aging. 2017;11(3):138-49. doi: 10.5327/Z2447-211520171700041

24. Cavalcante FCG, Martins DSS, Oliveira JS, Nóbrega AL, Martins FES, Martins MSS. Caregivers of Alzheimer's sufferes elderly. Rev Bras Educ Saúde [Internet]. 2015 [cited 2018 Dec 09]5(3):23-8. Available from: http://oaji.net/articles/2016/2628-1461602114.pdf

25. Garber CE, Blissmer B, Deschenes MR, Franklin BA, Lamonte MJ, Lee IM, et al. American College of Sports Medicine position stand: quantity and quality of exercise for developing and maintaining cardiorespiratory, musculoskeletal, and neuromotor fitness in apparently healthy adults: guidance for prescribing exercise. Med Sci Sports Exerc. 2011;43(7):1334-59. doi: 10.1249/MSS.0b013e318213fefb 
26. Virtuoso JF, Streit IA, Claudino R, Mazo GZ. Frailty indicators and physical activity level of the elderly. ConScientiae Saúde. 2015;14(1):99-106. doi: 10.1590/S0104-42302012000300015

27. Pinquart M, Sorensen S. Spouses, adult children, and children-in-law as caregivers of older adults: a meta-analytic comparison. Psychol Aging. 2011;26(1):1-14. doi: 10.1037/a0021863

28. Luchesi BM, Degani GC, Brigola AG, Pavarini SCI, Marques S. Evaluation of depressive symptoms in older caregivers. Arch Clin Psychiatry. 2015;42(2):45-51. doi: 10.1590/0101-60830000000047

29. Rodrigues NO, Neri AL. Vulnerabilidade social, individual e programática em idosos da comunidade: dados do estudo FIBRA, Campinas, SP, Brasil. Ciên Saúde Coletiva. 2012;17:2129-39.

30. Pedreira LC, Oliveira AMS. Caregivers of dependent elderly at home: changes in family relationships. Rev Bras Enferm. 2012;65(5):730-6. doi: $10.1590 /$ S0034-71672012000500003

31. Pegorari MS, Tavares DMS. Factors associated with the frailty syndrome in elderly individuals living in the urban area. Rev Latino-Am Enferm. 2014;22(5):874-82. doi: 10.1590/0104-1169.0213.2493

32. Feng L, Nyunt MSZ, Feng L, Mmed KBY, Ng TP. Frailty predicts new and persistent depressive symptoms among community-dwelling older adults: findings from Singapore longitudinal aging study. JAMDA. 2014;15(1):e76.e7-e12. doi: 10.1016/j.jamda.2013.10.001

33. Gale CR, Cooper C. Attitudes to ageing and change in frailty status: the English Longitudinal Study of Ageing. Gerontology. 2017;64(1):5866. doi: $10.1159 / 000477169$

34. Freire HSS, Oliveira AKS, Nascimento MRF, Conceição MS, Nascimento CEM, Araújo PF, et al. Aplicação da Escala de Depressão Geriátrica de Yesavage em instituições de longa permanência. Nursing [Internet]. 2018 [cited 2018 Dec 05]21(237):2030-5. Available from: http://www. revistanursing.com.br/revistas/237-Fevereiro2018/aplicacao_da_escala_de_depressao_geriatrica.pdf

35. Melo B, Moraes HS, Silveira H, Oliveira N, Deslandes AC, Laks J. Effects physical training on quality of life in older adults with major depression. Rev Bras Ativ Fis e Saúde. 2014;19(2):205-14. doi: 10.12820/rbafs.v.19n2p205

36. Macedo MASS, Oliveira VB, Oliveira AG, Abreu SSS, Duarte SFP, Lima PV. Depressive symptomology in elderly assets and non-assets. Rev Enferm UFPI. 2017;6(4):33-9. doi: 10.26694/2238-7234.6433-39

37. Perez-Peñaranda A. El cuidador primario de familiares con dependencia: calidad de vida, apoyo social y salud mental [Tese] [Internet]. Salamanca (ES): Universidad de Salamanca/Facultad de Medicina; 2006[cited 2018 Dec 08]. Available from: http://envejecimiento.csic.es/ documentos/documentos/perez-cuidador-01.pdf

38. Neri AL, Borim FSA, Fontes AP, Rabello DF, Cachioni M, Batistoni SST, et al. Factors associated with perceived quality of life in older adults: ELSI-Brazil. Rev Saude Publica. 2018;52(supl 2):16s. doi: 10.11606/S1518-8787.2018052000613

39. Barbosa MFL, Lages MGG, Lopes MB, Carvalho APR, Souza ATS, Gonçalves MMSR. Qualidade de vida dos cuidadores de idosos físicos dependentes: um estudo de enfermagem. Rev Portal Divulg [Internet]. 2015 [cited 2018 Dec 08]:46. Available from: http://www. portaldoenvelhecimento.com/revista-nova/index.php/revistaportal/article/viewFile/547/603

40. Anjos KF, Boery RNSO, Pereira R. Quality of life of relative caregivers of elderly dependents at home. Texto Contexto Enferm. 2014;23(3):6008. doi: 10.1590/0104-07072014002230013

41. Morley JE, Vellas B, van Kan GA, Anker SD, Bauer JM, Bernabei R, et al. Frailty consensus: a call to action. J Am Med Dir Assoc. 2013;14(6):3927. doi: 10.1016/j.jamda.2013.03.022

42. Rodríguez Jiménez KS, Reales Chacón LJ. Síndrome de fragilidad y sus variables asociadas. Med Interna (Caracas) [Internet]. 2016 [cited 2018 Dec 09]32(4):272-8. Available from: http://www.svmi.web.ve/ojs/index.php/medint/article/view/396/389

43. Alcântara AR, Cabral HMA, Freire ALL, Ferreira LGF, Torres MV, Rocha GM. Comparative analysis of quality of life among elderly women and non-physically active in Teresina - Piauí. Rev Eletr Gestão Saúde [Internet]. 2015 [cited 2018 Dec 08]5(5):3004-14. Available from: http:// periodicos.unb.br/index.php/rgs/article/view/13775/9709

44. Sánchez-García S, Gallegos-Carrillo K, Espinel-Bermudez MC, Doubova SV, Sánchez-Arenas R, García-Peña C, et al. Comparison of quality of life among community-dwelling older adults with the frailty phenotype. Qual Life Res. 2017;26(10):2693-703. doi: 10.1007/ s11136-017-1630-5 